\title{
INDIVIDUAL VARIABLES AND CRIME VULNERABILITY AMONG TEENAGERS IN SECONDARY SCHOOLS IN IKOM EDUCATION ZONE OF CROSS RIVER STATE - NIGERIA AND COUNSELING NEEDS
}

\author{
Dr. Okpechi, Philip A. \\ Department of Guidance and Counselling \\ Faculty of Education, University of Calabar \\ Dr. Ogar, A. Ambor \\ Department of Guidance and Counselling \\ Faculty of Education, University of Calabar
}

Citation: Philip A. Okpechi and Ambor A. Ogar (2022) Individual Variables and Crime Vulnerability Among Teenagers in Secondary Schools in Ikom Education Zone of Cross River State - Nigeria and Counseling Needs, British Journal of Education, Vol.10, Issue 2, pp. 13-21

\begin{abstract}
The very reason of this study was to investigate the influence of individual variables on crime vulnerability among teenagers in secondary school in Ikom Educational Zone, Cross River State, Nigeria. The independent variable is attitude to stealing while dependent variable was crime vulnerability. Descriptive survey design was adopted for the study. The population of the study was six thousand three hundred and thirty-nine (6.339) Senior Secondary three (SS 3) students in eighty-four public secondary schools in Ikom Education Zone. The sample of the study was 450 respondent selected form seventeen secondary schools in the study area. Proportionate sampling and simple random sampling technique were used to select the schools and subjects use for the study. The instrument used for data collection was researchers made questionnaire titled individual variables and crime vulnerability questionnaire (IVACVQ). The instrument was validated by two experts in Test and measurement and one Expert from Guidance and Counselling both from the University of Calabar, Calabar, Cross River State. Cronbach's alpha reliability coefficient estimates of the instrument were between .72 to 87 which indicated that the instrument was highly reliable. In order to achieve the purpose of the study, one null hypothesis was formulated and tested at .05 alpha levels using simple linear regression analysis. The result showed that students attitude to stealing have significant influence on crime vulnerability among the subjects. Based on the findings, it was recommended among others that counselors should direct counseling towards addressing teenage crimes - in the society.

KEY WORDS: individual, variables, teenage crimes, vulnerability
\end{abstract}

\section{INTRODUCTION}

Crime have become an everyday experience in the society (Nigeria). Different kinds of crimes are perpetrated on daily basis thereby creating insecurity to both young and old people. Business Dictionary (2019) defined crime as a harmful act of commission against the public 
which the government wishes to prevent and which upon conviction is punishable by imprisonment, fine or death. This implies that, crime is a violation of ethical and moral principles of the society. It is committed by the teenagers also adults.

Teenager can also be directed to as adolescent. Other words such as youth and juvenile can be used to describe a teenager. Teenager is unisex in the context of this research; therefore, teenager can be a boy or a girl who is within the age bracket of fifteen and nineteen years. In Nigeria teenagers are often found in secondary schools, and only a few of them are in the tertiary institutions of learning. Based on their nature, teenagers are often adventurous due to the fact they always want to experiment any action, they are usually of physical strength and vigor. They are physically strong and thus, can go miles in performing tasks because of the exuberant energy in them. This is why it is believed that teenagers are prone to crimes.

The teenage crimes are those crimes which committed by people who are within the above mentioned age bracket. Regrettably, crime committed by this category of people are mostly dangerous because their minds are not mature enough to really know the consequences of their doings. This age bracket, however, is the most sensitive period of life because, it is the time that decides the entire life of a person to a great extent whether she or he will become a responsible citizen or a criminal. It therefore means that if teenager crime are not checked, control or eradicated from an individual, he or she will grow up to become a criminal throughout the adult life.

Okon (2017) observed that the problem of teenage crimes cannot be viewed in isolation from other behaviour problems such as drug addict, prostitution, abortion, gangsterism, examination malpractices, truancy, theft and fraud. It has become very noticeable that these heinous lifestyles always interfere with people's safety, security and academic achievement, Greatly, the study of teenage crimes as crucial as it is, cannot be unique without looking at vulnerability.

The term vulnerability lacks a universal definition, however, Larkin (2009) define vulnerability as a state or condition where a person is in danger, under threat, at risk, and /or need support or protection. The above views suggest that vulnerability is not a stable state across situation and the lifespan. Vulnerability is relative and dynamic. Things and situations do not always remain the same. The changes in human conditions, experience and environment also necessitate the level and rate of his vulnerability. The relative and dynamic nature of human vulnerability is not different in the study of teenage crimes in the society.

The rising incidence of teenage crimes in recent times has become a critical issue in Nigeria and the world in general. In Cross River State, precisely in Ikom education zone, crimes have become a way of life for many young people. The issue of pick-pocketing, kidnapping, rioting, burglary, street fighting, cultism, raping and drug abuse are very common with youth. These negative lifestyles have spread across locations across the state so that no part of the study area is really considered to be safe. Some uncompleted buildings within this area have been converted to homes of area boys. There is emergence of new confraternity groups in the area of study, and usually, the society is the victim of the activities of cultists. Commuters face a lot of harassment form the "area boys" who are operating both day and night. The fear, 
intimidation, assault and loss experienced by people who fall prey to these criminals have left much to desire.

The bad side of teenage crimes cannot be over emphasized many young people have recently abandoned their academic career in pursuance of false freedom, power and support. Unfortunately, many of the youth who were deceived to join these gangs have not really enjoyed the freedom and power they were craving for. This leaves them in a state of misery and desperation, making them to commit more crimes. Some young people have turned to beggars, prostitutes and thieves or armed robbers. Many of them have been arrested and prosecuted while some are currently serving jail terms. The gains of teenage crimes are usually temporary. This is why; there are more cases of premature death in Ikom Education zone recently.

Again another criminal act observed among teenagers in recent times is cultism, a crime which result in assaults, intimidation and mayhem on the people, which is mostly frowned at by the society. The situation is worrisome as more cases of cultism emerge from different areas of the federation. Cultism has been a major power behind various crimes in the society. That is why teenagers who engage in cultic affiliation are said to be susceptible to other forms of crimes such as rape, alcoholism, gangsterism, vandalism, theft, drug abuse and killing. According to cable News and views Unlimited (2019), Cross River, Ebonyi and Bayelsa States rank first among the 36 states of the federation in terms of robbery, rape and murder. Consequently, the foreign and common wealth office of the United Kingdom has advised its citizens against travelling to 21 states in Nigeria with Cross River and Akwa Ibom States inclusive due to insecurity. The sources revealed that, of 165, 000 criminal cases recorded in 2015 about 14,000 involved students (cable news and views unlimited, 2019).

Attitude is a function of behaviour, it is described as the feeling or opinion about something or someone. It is believed that attitude may influence an individual's choice of action, and responses to challenges, incentives and rewards. The feeling a person has for something determines how he behaves towards such a thing. Teenager's attitude towards crime varies based on individual. Consequently, the degree of vulnerability also varies-hence crimes.

Vulnerability as earlier stated deals with the quality of being easily hurt, influenced or attacked physically, emotionally or mentally. In the context of dealing with criminality, people differ in vulnerability as a result of social group, individual variables and demographics. The researchers have been burdened with the dilemma of teenage crimes and vulnerability and want to find out with individual variables such as attitude to stealing influence crime vulnerability among teenagers in secondary schools in Ikom Education zone.

\section{Problem and purpose of the study}

The tense atmosphere observed in some secondary schools in Nigeria and especially in Cross River State is so fearful. Secondary school students in some cases possess dangerous weapons such as axes, guns and knives it is even worrisome to observe that teenagers are involved in the act of terrorism. It is common these days to observe secondary school students carry out riots, challenge their teachers, fight and maim fellow students. What surprises the researchers is the courage and will power which theses youth possess to carry out these acts, and their involvement in these social vices instead of focusing on their studies which could make them 
live happy and fulfilled lives. A lot had been done to curb criminal acts among teenagers in Nigeria. Religious organizations have mounted many crusades and lectures to discourage youth from engaging in criminal acts. Government had enacted laws to prohibit criminal acts and many have been arrested and prosecuted on the account of violating criminal laws. Social workers have also carried out sensitization programmes to enlighten the public on the dangers of criminality. All these efforts are meant to eradicate teenage crimes in the society, yet the problems have continued. What then could have been the cause of this problem? Could it be the students' attitude that could make them vulnerable to crimes? It is against this development that the researchers are moved to investigate the influence of individual variables on crime vulnerability among secondary schools in Ikom Education zone, Cross River State, Nigeria. Taken together, therefore, the study is intended to investigate the influence of individual variables on crime vulnerability among secondary schools in Ikom Education Zone. Therefore, the study specifically intended to: Find out whether there is significant influence of attitude to stealing on crime vulnerability among teenagers in the area of study.

\section{RELATED LITERATURE}

This section has reviewed related literature under the sub-variable; students' attitudes to stealing and crime vulnerability of teenagers.Attitude can be viewed as manner, disposition, feeling and position with regard to a person, thing, tendency or orientation, especially in the mind. To Cherry (2019), attitude is the result of experience or upbringing. This view of Cherry makes it sensible to attribute teenage attitudes to home and other learning environments that can impact experience on the individuals. Holistically, attitude includes a set of emotions, beliefs and behaviours towards a particular object, person or event.

Three components of attitude have been identified. They include cognitive component which deals with an individual's thoughts and beliefs about a phenomenon. This is where the power of self-confidence resides. The second component is affective component also referred to as emotion. It controls the seat of feelings and deals with how an individual feel about a phenomenon. This is why people react to issues or situations differently. The third component of attitude is called behavioural component which shows how an individual is influenced by a phenomenon. Vulnerability therefore depends on the three components of students' attitudes. The thought process, the feeling process and the response to a situation, all added together impact on the degree of vulnerability. This is to say that vulnerability is entirely individualistic since vulnerability is consequent upon behaviour.

Generally, attitudes are formed directly, from experience. They may emerge due to direct personal experience, or they may result from observation. This view makes attitude to be explicit and extrinsic. Some psychologists however, have argued that attitude is a product of a biological gene, and that inherited traits are responsible for attitudes. Despite the arguments, it is often believed that attitudes have been biological and ecological functions. In finding out the reason why people attitudes to events vary, Hayati (2919), categorized attitude into two types namely, positive and negative attitudes. According to Hayati, positive attitudes are the organizational behaviours. They enable people to think about and concentrate on the good, regardless of the circumstances. The positive attitudes give strength, energy, motion and 
initiative. The people with positive attitude possess the power of confidence, happiness, security and determination. That is why they cannot be easily hurt or hindered by prevailing circumstances. On the other hand, individuals with negative attitudes have low selfconfidence. They are pessimistic, indifferent and usually resort to unconstructive criticisms Hayati (2019). Often, it appears that, the negative thinkers look frustrated and blame their failures on people, events and circumstances that surround them. Several empirical studies have shown correlations between attitudes and crime vulnerability.

Fasanmi (2015) investigated the influence of psycho-social factors on youth's attitude toward internet fraud in Nigeria. The opinions of 200 undergraduates in the department of computer science in Benue State University, Makurdi were randomly sampled for the study. A battery of test such as Big-five personality inventory need Achievement questionnaire and attitude towards internet fraud questionnaire were used as instrument to collected data from the subjects. The analysis of data revealed that extraversion, psycholicism, neuroticism among others significantly predicted youth's attitude towards internet fraud. It was recommended that Africans should re-examine their culture to reflect acceptable lifestyles on the child from birth.

Similarly, Rotimi (2019) investigated youth's attitudes towards internet crimes. The researcher adopted a survey design to sample 130 internet users form universities across Lagos state, Nigeria. The data obtained were analyzed using analytical techniques such as pearson's correlation and hierarchical regression. Based on the findings of the study, it was concluded that there is significant effect of age, sex, belief, knowledge, and involvement factor on the youth's involvement in internet crime.

The teenage stage is a period of transition in which, teenagers feel pressured to have their first intimate relationships. Consequently, some of them often use negative attitudes to approach their opposite sex in attempt to satisfy their quest for intimacy. A study by Jessika, Nina and Teresa (2017) showed that teenage vulnerability to crime depends on whether they have supportive attitude towards crime. The study which mainly carried out to examine the level of knowledge of Swedish young people regarding sexual crime and the supportive attitudes of students. A sample of 245 upper secondary school students (aged 16-19 old) was selected from five schools in four Swedish countries, using a purposive sampling procedure. The results indicated that adolescents in Sweden have high level of knowledge of rape, sexual molestation or harassment, and sexual exploitation of a dependent person. The study showed nonsupportive attitude to rape, sexual harassment, and sexual crime in general.

In the study of Stone and Couch (2004), teachers' attitudes, perception and responses towards peer sexual harassment among high school students was investigated in Texas 270 respondents were used as sample, randomly selected from 20 high schools. The results showed that teachers were intolerant in their attitudes towards sexual harassment. The set of four predictors: age, sex, sexual identity and size of school; however, influenced the teachers' response to peer harassment. What this findings mean is that teachers' attitude influence students' attitudes on sexual harassment, thus, when the attitude of the teacher who is surrogate mother is uncompromising the students will retract their steps towards sexual harassment and vice versa. 


\section{RESEARCH METHOD}

The study adopted a survey design. According to Isangedighi (2012), survey design is a method of having a systematic, intense, accurate and purposeful observation of behaviour, trait or opinion and describing same as precisely as possible. The survey method is used when a study is conducted on a large population using questionnaire as instrument to collect data. Survey design is suitable when a researcher is investigating individual characteristics of independent variables. This study investigated the influence of personal variables on crime vulnerability among teenagers therefore, survey design was quite suitable. The design was chosen to enable the researchers to assess a large population and thus required an intense study of the variables involved.

The sample of this study consisted of 450 senior secondary three students (SS 3) in seventeen (17) public secondary schools selected form Eighty-four (84) secondary schools in Ikom Education Zone. Out of the 450 subjects selected, 236 were males while 234 were females. The sample distribution of students in public secondary schools is presented on Table 1.

Table 1: Sample of SS3 students in Ikom Education Zone of Cross River State by Local Government Area schools and sex

\begin{tabular}{|c|c|c|c|c|c|}
\hline $\mathbf{S} / \mathbf{N}$ & $\begin{array}{l}\text { LOCAL Government } \\
\text { Areas }\end{array}$ & $\begin{array}{l}\text { Sample } \\
\text { schools }\end{array}$ & Males & Females & $\begin{array}{l}\text { Students } \\
\text { sampled. }\end{array}$ \\
\hline 1 & Boki & 4 & 24 & 5 & 29 \\
\hline 2 & Etunk & 1 & 7 & 8 & 15 \\
\hline 3 & Ikom & 5 & 25 & 16 & 41 \\
\hline 4 & Obubra & 3 & 116 & 106 & 222 \\
\hline 5 & Yakurr & 1 & 45 & 61 & 106 \\
\hline \multirow[t]{2}{*}{6} & Abi & 3 & 17 & 20 & 37 \\
\hline & Total & 17 & 234 & 216 & 450 \\
\hline
\end{tabular}

\section{RESULT}

In order to determine the influence of attitude to stealing on crime vulnerability among teenagers in Ikom Education Zone. Simple linear regression analysis was used.

\section{Hypothesis 1}

The null hypothesis states that there is no significant influence of attitude to stealing on crime vulnerability among teenagers in Ikom Education zone. To test this hypothesis, simple linear regression analysis was used to compare students' attitude to stealing and crime vulnerability among teenagers in Ikom Education zone. The result is presented in Table 2.

Table 2: Summary of sample Linear regression analysis of the influence of students" attitude to stealing on crime vulnerability among teenager in Ikom Education Zone, Cross River State $(\mathrm{N}-450)$ 
Vol.10, Issue 2, pp. 13-21, 2022

Online ISSN: 2054-636X (Online)

Print ISSN: 2054-6351(Print)

\begin{tabular}{|c|c|c|c|c|c|}
\hline Model & $\mathrm{R}$ & $\mathrm{R}^{2}$ & Adj. $R^{2}$ & Std error of Estimate & \\
\hline Students attitude & 6 & 14.442 & 2.896 & $* 247$ & 00 \\
\hline Crime vulnerability & 12 & 28.106 & 7.462 & & \\
\hline
\end{tabular}

\begin{tabular}{|c|c|c|c|c|c|c|}
\hline \multicolumn{7}{|c|}{ - $\quad$ Significant at 0.05 level of significance } \\
\hline Model & $\mathrm{R}$ & $\mathrm{R}^{2}$ & Adj. $R^{2}$ & \multicolumn{3}{|c|}{ Std error of Estimate } \\
\hline 1 & .010 & .000 & & & & \\
\hline & & ANOVA & -.002 & & .50096 & \\
\hline Model & Ss & df & $\mathrm{ms}$ & $\mathrm{F}$ & Sig & \\
\hline 1 Regression & .012 & 1 & 001 & .048 & .837 & \\
\hline Residual & 113.442 & 448 & .251 & & & \\
\hline Total & 113.444 & 449 & & & & \\
\hline \multicolumn{7}{|c|}{ Coefficients } \\
\hline \multirow[t]{2}{*}{ Model } & Unstandardized & \multicolumn{2}{|c|}{ Coefficients } & Standardized & Coefficients & \\
\hline & $\mathrm{B}$ & \multicolumn{2}{|l|}{ Std Error } & Beta & $\mathrm{T}$ & Sig \\
\hline 1 (constant) & 1.493 & \multicolumn{2}{|l|}{.089} & & 16.738 & .000 \\
\hline \multicolumn{2}{|c|}{ Attitude to stealing .001} & .007 & & .010 & .318 & .837 \\
\hline
\end{tabular}

*Significant at 0.05 level of significance

The result of the analysis in table 2 shows that there is a significant level of students' attitude to stealing on crime vulnerability among $(\mathrm{B}=0.0 \mathrm{i} 0 ; \mathrm{t}=03 \mathrm{i} 8 ; \mathrm{P}>0.05)$. Given that the result of the analysis is statistically significant at 0.05 level, the null hypothesis which states that there is no significant influence of students' attitude to stealing on crime vulnerability among teenagers in the study area is rejected while the alternate hypothesis is retained. This implies that, there is a great influence of students' attitude to stealing on crime vulnerability among teenagers in Ikom Education zone.

\section{DISCUSSION}

Relative to hypothesis one which stated that there is no significant influence of attitude to stealing on crime vulnerability or teenagers in the study area, this null hypothesis was rejected. The result does not come short of expectation given the present negative attitude observed among teenagers in Ikom Education Zone and its environs in recent times. The findings gives a true picture of situation of teenagers in the $21^{\text {st }}$ century in which, the attitude of teenagers were widely influenced by the internet and other social media platforms, which have negatively influenced the life of young people. Studies have shown that young people spend longer time on cell phones more often than adults, and this affected their attitude.

This result is in agreement with the findings of Fasanmi (2015) who examined the influence of psycho-social factors on youths towards internet fraud in Nigeria and found out that, extraversion, psychoticism, neuroticism among others significantly predicted youth's attitude towards internet fraud. The study is also supported by the views of Hatati (2019) who stated that people with negative attitude have low self-confidence. They are pessimistic, indifferent and usually resort to unconstructive criticisms. It is therefore, interested to note that students who have negative attitude towards opposite sex would likely demonstrate ill behavior such as 
sexual harassment and force sex as they come across their counterpart, most especially in an isolated environment. Furthermore, lack of self-control may lead students to stealing of properties that are not theirs.

\section{CONCLUSION/RECOMMENDATIONS}

From the findings of the study attitude to stealing influence crime vulnerability of teenagers in secondary schools. This implies that if students exhibit proper attitude such as self-control, discipline and abstinence, they will be able to resist the force of criminality. Based on these: 1. There is need for counselors in schools and non-school settings to direct their efforts towards addressing teenage crimes with emphasis on rape, drug abuse, stealing, violent behavior and cultism in order to offer adequate interventions that will nip teenage crimes in the bud.

2. Teachers should as a way of necessity ensure that they incorporate moral values in all teaching and learning experiences in order to instill good virtues and ethical behavior in learners.

3. Parents, guardians and caregivers should provide the necessary training and discipline at home and should endeavour to report their children or ward's bad ways to the school authority for a combined effort to combat crime in the society.

\section{References}

Cable News and Views unlimited. (2019) full list: Uk warn citizens against trips to 21 Nigeria states. Retrieved from https://www.the cabe.ng/uk-warns-citizens-against-trip-toakwa-ibom-kogi-21-states on Friday $9^{\text {th }}$ December, 2021 at 7.34am.

Cherry K. (2019). Attitudes and behavior in psychology. Retrieved at https://www.verywellmind.com/attitudes-how-they-form-change-shape-behaviour2795891.

Couch, O. (2004) The need for rethinking the concept of vulnerability and risk from holistic perspective: a necessary review and criticism for effective risk management. Mapping vulnerability: disasters dev. And people.

Fasanmi, S. (2015) Influence of psycho-social factors on youth's attitude towards internet fraud in Nigeria. Retrieved from https: www.researchgate.net/publication /277948014 influence - of - psycho-social-factors on -youth's attitude -towards- internet - fraud in - Nigeria.

Hayati (2019) Influence of personality traits and continuation intentions on physical activity participation within the theory of planned behavior. Psychological and Health, 23(3), 447-368

Isangedihi, A. (2012) (Eds). Essentials of Research and Statistics in education and social science. Calabar, Eti-Nwa Associates Research and publishers.

Jessika, S, Nina, B. and Teresa (2017). Knowledge of Swedish young people regarding sexual crime and the supportive attitude of students. Journal of sexual Aggression: An international, interdisciplinary forum for research Theory and practice. 25 (2); 75-89.

Okon, C. (2017) |Relationship between drug Abuse and psychological Behaviours among adolescents in senior secondary schools in cross River State- Calabar Counsellor". Counselling association of Nigeria (CASSON), 6 (1) 1-13 
British Journal of Education

Vol.10, Issue 2, pp. 13-21, 2022

Online ISSN: 2054-636X (Online)

Print ISSN: 2054-6351(Print)

Rotimi, W. (2019). Youth's attitude towards internet crime: social factors causes and effects. Retrieved at https:// www. Researchgate.net/publication/ 332539693-youth's-attitudetowards- internet-crime-social-causes-and-effects 